\title{
Floristic similarities of the Artinskian Siderópolis Member macroflora, Rio Bonito formation (Paraná Basin, Brazil) with Cisuralian paleofloras of India
}

\author{
Similaridades florísticas da macroflora artinskiana do Membro Siderópolis, \\ Formação Rio Bonito (Bacia do Paraná, Brasil) com as paleofloras cisuralianas da Índia
}

\author{
Mary Elizabeth Cerruti Bernardes-de-Oliveira ${ }^{1}$, Pauline Sabina Kavali ${ }^{1,2}$, Sandra Eiko Mune', \\ Maria Judite Garcia ${ }^{1}$, Mahesh Shivanna ${ }^{3}$, Roberto lannuzzi ${ }^{3}$ and Karoline Gonçalves Pereira ${ }^{4}$ \\ 'Universidade de São Paulo - USP, Instituto de Geociências, Departamento de Geologia Sedimentar e Ambiental - GSA, \\ Laboratório de Paleobotânica e Palinologia, Programa de Pós-graduação em Geoquímica e Geotectônica, Rua do Lago, 562, \\ CEP 05508-080, São Paulo, SP, Brazil (maryeliz@usp.br; paulinesabina@gmail.com; smune@hotmail.com; mjudite@usp.br) \\ ${ }^{2}$ Birbal Sahni Institute of Palaeosciences, Lucknow, India \\ ${ }^{3}$ Universidade Federal do Rio Grande do Sul - UFRGS, Instituto de Geociências, Porto Alegre, RS, Brazil \\ (mahesh.shivanna@ufrgs.br; roberto.iannuzzi@ufrgs.br) \\ ^Universidade Guarulhos - UnG, Guarulhos, SP, Brazil (karolthgermany@gmail.com)
}

Received on April $1^{\text {st }}, 2016$; accepted on September 16 $6^{\text {th }}, 2016$

\begin{abstract}
This contribution focuses on the relationship between the Siderópolis Member paleoflora and Indian Gondwanan paleofloras, especially with those of the Cisuralian stages, thus providing additional criteria for the correlation of Western and Eastern Gondwanan coal successions in the lower Permian interval. Despite the large number of species in common with the Karharbari Stage (Sakmarian) flora, the Siderópolis paleoflora exhibits a higher percentage and diversification of the genus Glossopteris, which is less expressive in the Karharbari Stage floras, while the declining Gangamopteris-Noeggerathiopsis complex in Siderópolis Member paleoflora still dominates the associations of Karharbari Stage. However, the floristic composition of the lower level of the Barakar Stage (Artinskian), despite having fewer species in common with the Siderópolis paleoflora, exhibits the characters of the latter vis-à-vis the dominance and diversity of the genus Glossopteris over the Gangamopteris-Noeggerathiopsis complex, which decreases both in diversity as well as in abundance in the lower Barakar, similar to what occurs in the Brazilian paleoflora. The decline of the icehouse stage and the similar latitudinal position of the Gondwanan regions compared in the present study seem to have acted as important factors to the development of similar vegetation patterns in coal floras from Western (Brazilian) and Eastern (Indian) Gondwana during the Artinskian.
\end{abstract}

Keywords: Glossopteris; Western Gondwana; Eastern Gondwana; Artinskian.

\section{Resumo}

Esta contribuição visa à comparação entre a paleoflora do Membro Siderópolis e as paleofloras dos andares cisuralianos das bacias gondvânicas indianas, oferecendo assim critérios adicionais para a correlação das sucessões carvoeira gondvânicas ocidentais e orientais, no intervalo do Permiano inferior. Apesar do grande número de espécies em comum com as floras do Andar Karharbari (Sakmariano), a paleoflora Siderópolis apresenta maior percentagem e diversificação do gênero Glossopteris, menos expressivas nas floras do Andar Karharbari, enquanto o complexo Gangamopteris-Noeggerathiopsis, declinante na paleoflora do Membro Siderópolis, ainda domina nas associações do referido andar indiano. Entretanto, a composição florística do nível inferior do Andar Barakar (Artinskiano), apesar de apresentar menos espécies em comum com a paleoflora Siderópolis, caracteriza-se pelo domínio e diversidade do gênero Glossopteris sobre o complexo Gangamopteris-Noeggerathiopsis, que diminui tanto em diversidade como em abundância no Barakar inferior, semelhante ao que ocorre na paleoflora brasileira aqui estudada. O declínio do estágio icehouse e a posição latitudinal semelhante das regiões gondvânicas aqui comparadas, durante o Artinskiano, teriam atuado como fatores importantes no desenvolvimento de padrões de vegetação similares nas floras geradoras de carvões no Gondwana Ocidental (Brasil) e no Oriental (Índia).

Palavras-chave: Glossopteris; Gondwana ocidental; Gondwana oriental; Artinskiano. 


\section{INTRODUCTION}

The upper Paleozoic Gondwana paleobotanical scenario shows a drastic floral change at the Asselian-Sakmarian boundary with the appearance of glossopterids and the disappearance of most of the Late Carboniferous elements, as a result of ameliorated climatic conditions. This interval includes the earliest stages of ice-free conditions during which a typical Glossopteris flora, adapted to cold and cool climates, replaced the ice sheets (Iannuzzi, 2013; Jasper et al., 2013). The classic Lower Gondwana sequence, from tillites to coal-swamp deposits, indicates a major climate warming from a cold to a cool temperate biome for the Permian of Gondwana (Ziegler et al., 1997; Rees, 2002; Rees et al., 2002) which led to the formation of Permian coals and the associated clastic deposits across the Gondwana supercontinent. Paleogeographic reconstructions (Scotese, 2002) show that in Paraná Basin the peat deposition occurred during the early/middle Permian at $50^{\circ} \mathrm{S}$ of paleolatitude under a cool temperate climate as reported from the Zambezi Basin and India (Rees et al., 1999).

Global geographic patterns of Permian climates were reconstructed by Rees (2002) showing a significant latitudinal climate gradient similar to the modern interglacial situation associated to environmental variables such as vegetation, topography and geography. The lowland-wetland and peat generating plant associations were components of a Glossopteris flora, dominated by sub-arborescent and herbaceous lycopsids, ferns, and pteridosperms (including glossopteris) besides, cordaitaleans, rare ginkgoaleans and conifers. The same plant groups were present in almost all parts of the southern hemisphere but with different diversity and dominance patterns in different sites and also in distinct stratigraphic levels (Cúneo, 1996; Jasper et al., 2013).

This contribution focuses on relationship between the Siderópolis Member paleoflora with those from different Permian Indian Basins, especially with the paleofloras of the Karharbari and Barakar stages, thus offering additional criteria for the correlation of Western and Eastern Gondwanan coal succession during the Permian interval.

\section{GEOLOGIC AND STRATIGRAPHIC SETTINGS}

\section{Brazilian western Gondwana}

The Paraná Basin is a vast area of about 1.6 million $\mathrm{km}^{2}$ with $7,000 \mathrm{~m}$ thick sediments, located in the central-southeastern part of the South American continent, distributed among the countries of Brazil, Argentina, Uruguay and Paraguay. It consists of a magmatic-sedimentary succession deposited between the Middle Ordovician ( $465 \mathrm{Ma})$ and the end of Late Cretaceous ( $65 \mathrm{Ma}$ ) and is marked by subsidence and uplift cyclical events. Phases of sedimentation are related to four subsidences, resulting in the development of the sedimentary supersequences limited by regional unconformities (Milani, 1997; Milani et al., 2007) as seen in Figure 1.

The Gondwana I Supersequence (Late C-Early Tr) corresponds to the third subsidence phase which began after a long erosion period when the sedimentary build up restarted in the basin during the Moscovian $(\sim 310 \mathrm{Ma})$ northward migration of the Western Gondwana. It is a second-order transgressive-regressive cycle and the thickest of the basin with approximately $2,800 \mathrm{~m}$ in its depocenter resulting from the Panthalassa invasion over the Gondwanan inland. This Supersequence includes seven Third-Order Sequences, named as Lower Permian Third Order Sequence 1 to 7 (LPTS-1 to 7) after Holz et al. (2010).

The basal transgressive interval corresponds to lithostratigraphic units known as the Itararé Group (diamictites, sandstones and siltstones/mudstones of periglacial origin), the Rio Bonito Formation (fluvio-paralic and lagoon back-barrier models to marine facies association) which include the coal-bearing-strata and the Palermo Formation (maximum marine transgression).

The overlying regressive package (Passa Dois Group) represents a continental trend and comprises Irati, Serra Alta, Teresina and Rio do Rasto formations, topped by fluvio-eolian deposits of the Sanga do Cabral and Piramboia formations (Menezes, 2000; Milani et al., 2007).

Although some coal seams occur in interglacial strata of Itararé Group, the coal occurrences of Paraná Basin are mostly assigned to the Rio Bonito Formation, deposited in Sakmarian-Artinskian interval. Peat formation occurred adjacent to paralic, estuarine, deltaic, backshore and shore face siliciclastic deposition in back-barrier coastal swamp environments (Holz et al., 2002, 2010).

\section{Indian eastern Gondwana}

The Gondwana basins of India are intracratonic surrounded by Precambrian terrains. They occur along major river valleys and are named after the rivers Damodar, Son, Mahanadi, Pranhita-Godavari, etc. or after the linear hill ranges like Satpura and Rajmahal. The Gondwana strata of Peninsular India register the sedimentation beginning in the Permo-Carboniferous period after a long depositional hiatus since the Proterozoic. The Gondwana successions are preserved in numerous discrete, basins that record a depositional history up to the Cretaceous (Mukhopadhyay et al., 2010; Khan and Shahnawaz, 2013). See Figure 2.

In India, as in Brazil and other parts of Gondwana, the successions start with basal diamictites and glacial outwash deposits, going up to coal-bearing siliciclastics (sandstones, siltstones and shales) with Glossopteris flora covered by Triassic red beds, further to Lower Cretaceous, with intercalated basic volcanic Jurassic rocks constituting 


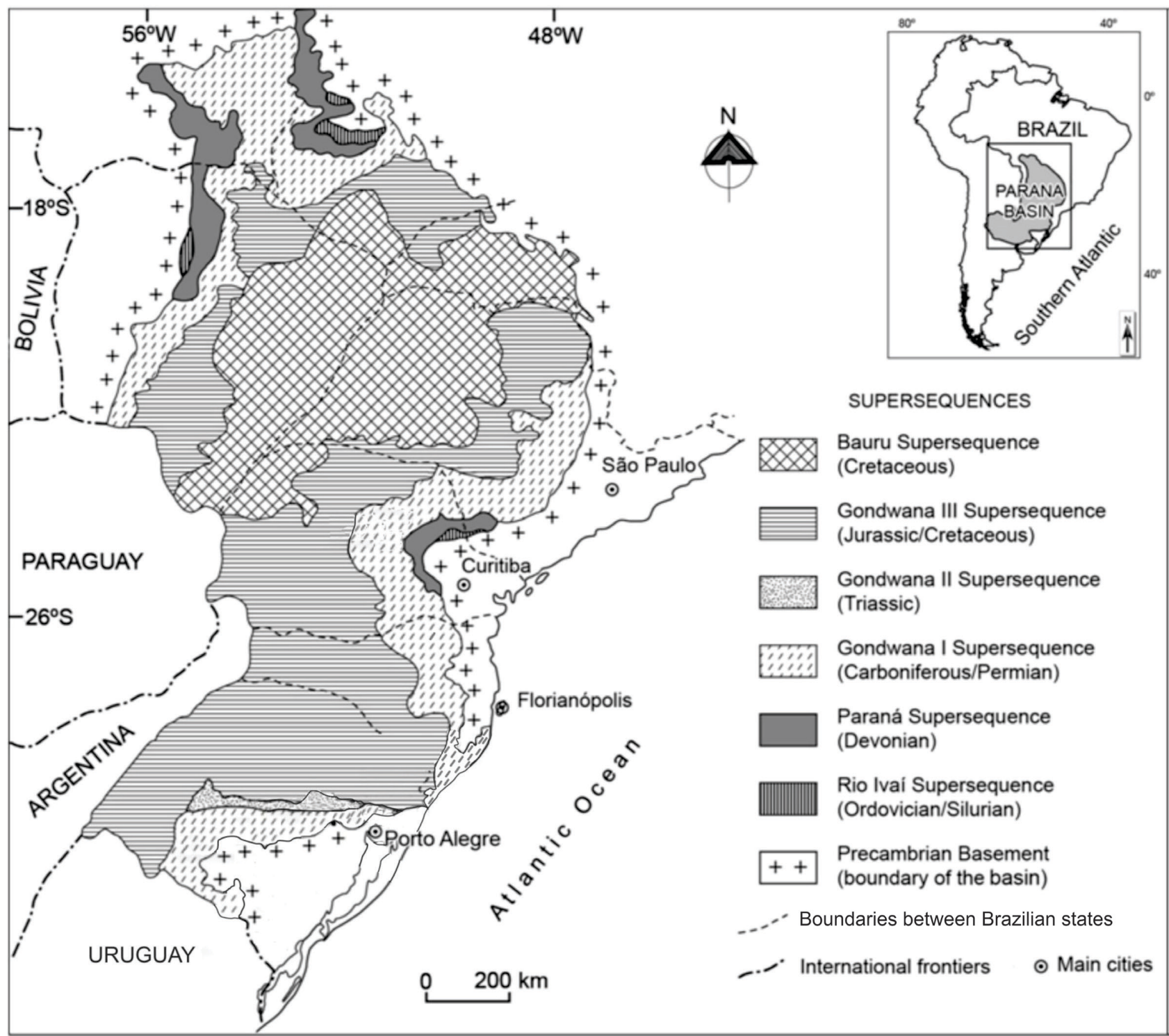

Figure 1. Paraná Basin location in the South American continent and its sedimentary Supersequences (modified from Milani et al., 1998).

more than 5,000 $\mathrm{m}$ thick sediments, deposited over 200 million years (Mukhopadhyay et al., 2010; Khan and Shahnawaz, 2013).

\section{THE BRAZILIAN AND INDIAN CISURALIAN PALEOFLORAS AND THEIR SIMILARITIES}

The oldest Indian interglacial and immediate postglacial fossiliferous strata, aging from Gzhelian to Sakmarian, are found in the Talchir Series which is divided into two stages: the lower stage called Talchir and the upper called Karharbari (Pant, 1996; Bernardes-de-Oliveira et al., 2011, Figure 2).
The taphofloras of the Talchir Stage are poor and suggest extreme cold conditions for plant growth, which probably took place during interglacial intervals or in periglacial non peat-generating environments (Chandra and Chandra, 1988; Chandra et al., 1992; Pant, 1996; Maheshwari and Bajpai, 2001; Srivastava and Agnihotri, 2010a). The Talchir flora (Gzhelian to Asselian) was characterized by a predominance of Gangamopteris species, both in number and diversity (Maheshwari, 1992; Pant, 1996; Srivastava and Agnihotri, 2010a, 2010b) followed by Noeggerathiopsis. Glossopteris leaves are rare and a weak representation of conifers and ferns has been registered (Maheshwari and Bajpai, 2001). This floristic association was assigned to the Gangamopteris floral phase by Navale and Saxena (1989) or Panthophyllum 


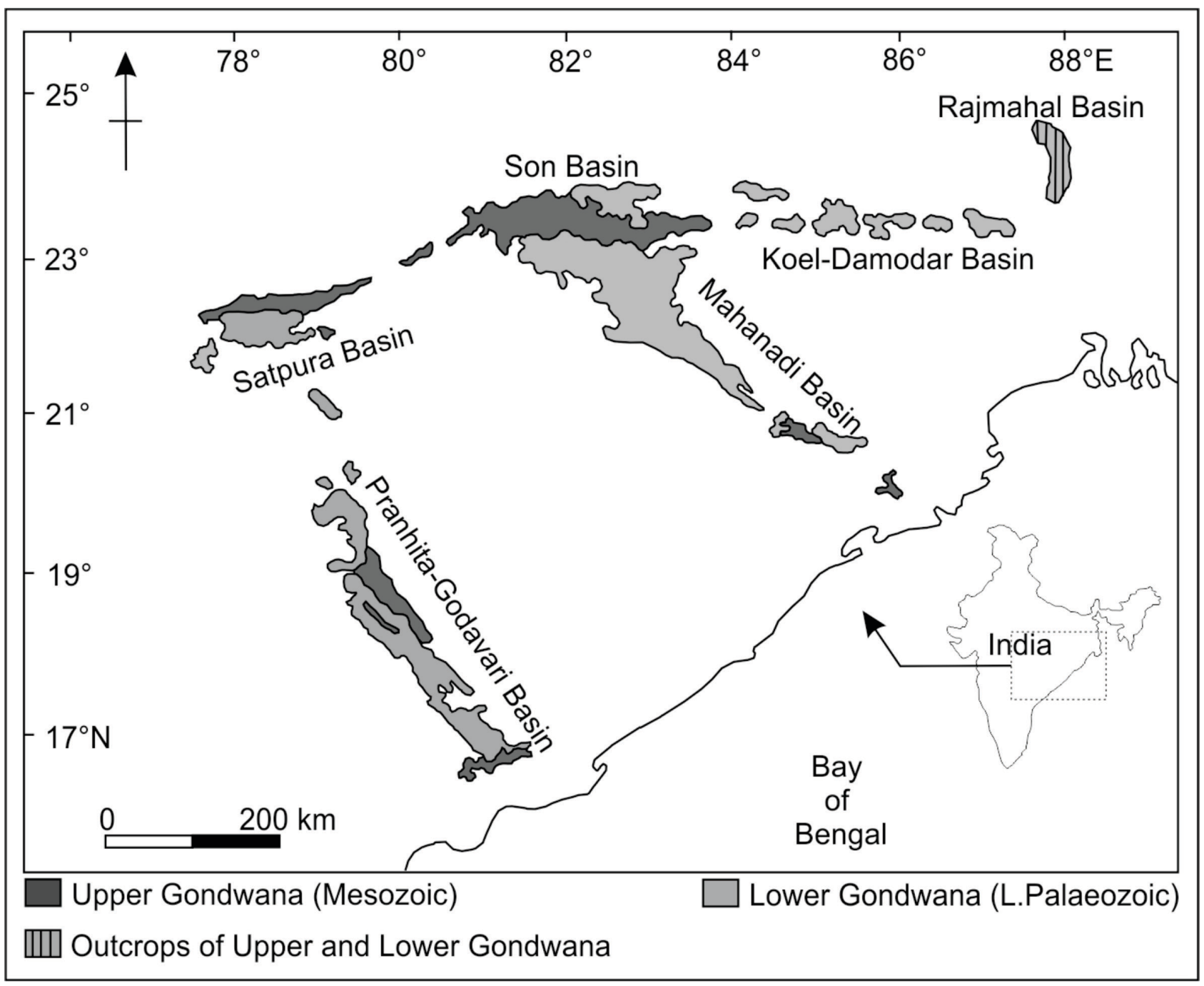

Figure 2. Gondwanan Basins of India. Source: modified from Khan and Shahnawaz (2013).

spathulata-Paranocladus indica Assemblage Sub-zone (Maheshwari and Bajpai, 2001). It must be mentioned that the lowest portion of the Talchir Stage contains only Gangamopteris with apparent absence of Glossopteris while the upper Talchir Formation consists of $75 \%$ of Gangamopteris against 25\% of Glossopteris (Srivastava and Agnihotri, 2010a).

A comparison of the Siderópolis paleoflora with that of the Talchir Stage reveals in common the occurrence of Gangamopteris cf. G. buriadica, G. intermedia and $G$. obovata (= G.cyclopteroides and G. major). Further in common are the presence of Glossopteris communis, Arberia genus and seeds of Cornucarpus furcata (Sur. and Lele) Maithy [= Maheshwariella furcata (Sur. and Lele) Mah. and Tew.] (Maheshwari, 1992). Nevertheless the feature that distinguishes these floras is their quantitative compositions, as in the Talchir Stage the predominance of the "Gangamopteris-Noeggerathiopsis Complex" indicates ancestry in relation to the Siderópolis paleoflora (Tables 1-3).

The flora of the Talchir Stage was succeeded by a floristic association (registered from the Karharbari Stage onwards up to the upper Barakar Stage) developed under a changing paleoclimatic regime from extreme cold towards a milder climate, which is characterized by the appearance of petiolate Glossopteris foliage with midrib, abundant pteridophytes and pteridosperms, as well as gymnosperm wood with growth rings. This floristic association was identified as Glossopteris floral phase by Navale and Saxena (1989).

According to Maheshwari (1992) and Pant (1996), the milder climatic conditions during the Karharbari (Sakmarian) Stage were favorable for the development of floras showing high diversity patterns in the Indian Peninsula, which have generated extensive peat accumulation and the generation of thick coal seams. The general coal-bearing succession in Indian Gondwana include distinct genetic coal types which 
were generated based on the paleogeographic and tectonic framework of the coal basins, paleoclimates and the floras of the coal-forming swamps (Navale, 1979).

A comparison of the Sakmarian Karharbari Stage (also included in the Talchir "Series") paleoflora with that of the Gzhelian-Asselian Talchir Stage paleoflora shows a significant increase in the generic and specific diversity: twenty species and two varieties were described among the Gangamopteris genus and fourteen species of Glossopteris genus, thus indicating a difference in the diversification pattern of the two genera.

Regarding Noeggerathiopsis genus, an increasing diversity is observed represented by eleven species in Karharbari Stage against only one species in the Talchir Stage (Pantophyllum spathulata $=$ Noeggerathiopsis spathulata $)$.

Besides the glossopteris and cordaitaleans mentioned above, the following forms are also in common with Siderópolis Paleoflora: Cordaicarpus zeilleri, Cornucarpus furcata (= Maheshwariella furcata), Ottokaria cf. O. bengalensis, three species of Gangamopteris, six species of Glossopteris and some genera in common like Rhabdotaenia, Arberia (including Dolianitia), Buriadia, Palmatophyllites, Samaropsis and Cyclodendron (See Tables 1-3).

Nevertheless, despite the generic and specific correlation, the quantitative composition of floristic elements is very distinct, since in Karharbari Stage, the dominance of gangamopterid species is still observed, in both variety and number while, in Siderópolis paleoflora the domain of Glossopteris over Gangamopteris (about 4:1) is clear besides the reduced occurrence of Noeggerathiopsis and the comparatively more diversified occurrence of fructifications related to Ottokaria.

As concluded by Bernardes-de-Oliveira (1980a), the Karharbari Stage is one of the five stages related to the Glossopteris flora, which constitutes the Indian Lower Gondwana, which has a greater number of species in common with the Siderópolis paleoflora (eleven species). However, the Gangamopteris-Noeggerathiopsis complex still dominates in this stage unlike that of Siderópolis paleoflora, where this complex is subordinated by the quantity of specimens and number of species of the Glossopteris genus.

The Damuda Series (Artinskian to Lopingian) overlies the Talchir Series and includes the following intervals from the base to the top: Barakar Stage (Lower and Upper Barakar formations), Barren Measures Stage (=Barren Measures /Motur Formation / Kulti Beds / Ironstone Shales Formation) and Raniganj Stage (=Raniganj /Bijuri /Lower Kamthi formations). The Triassic Panchet Series overlies the Damuda Series.

A cool climate interval has been suggested for the Barakar Stage (lower Barakar $=$ Artinskian and upper Barakar $=$ Kungurian) as it is characterized by an increasing enrichment of floras and expansion of peat accumulation which have originated the thicker Gondwanan coal measures
(134 meters in Jhingurda) (Pant, 1996; Mukhopadhyay et al., 2010). Marked seasonal climatic changes are reflected by growth rings in the petrified woods of the Barakar Stage (Pant, 1996). The strata included in this interval contain a diverse megafloristic assemblage that includes glossopteris, sphenophytes, pteridophylls, pre-conifers and possible ginkgophytes. The Glossopteris genus, represented by seventeen species becomes the dominant plant taxon while Gangamopteris showing five species are relegated to a secondary position. Noeggerathiopsis decline both in diversity and in abundance and is represented by only two species. Other glossopteris taxa such as Rhabdotaenia and Pterophyllum, Vertebraria axes and fructifications of Dictyopteridium lanceolatus and Ottokaria type are also common (Pant, 1996; Maheshwari and Bajpai, 2001).

The sphenophytes are much diversified represented by Lelstotheca, Paracalamites four species of Phyllotheca, Schizoneura gondwanensis and three species of Sphenophyllum. The pteridophytes are also markedly diversified represented by Alethopteris, Sphenopteris, Neomariopteris and Pecopteris. The pre-conifer Buriadia heterophylla persists and the Walkomiella indica appears, as well as new forms of putative ginkgophytes such as Barakaria dichotoma and Rhipidopsis besides eight taxa of seeds (Pant, 1996).

The taxa in common between the Siderópolis paleoflora and the floras of the lower Barakar stage (Artinskian) are the following thirteen species: Phyllotheca australis, P. griesbachii, Gangamopteris cf. G. buriadica, G. intermedia, G. obovata (= G. major), Glossopteris ampla, G. angustifolia, G. browniana, G. communis, G. cf. G. longicaulis, G. taenioides, Noeggerathiopsis hislopii, Cordaicarpus zeilleri. Further, seven genera are in common: Lepidostrobus, Ponsotheca (= Neomariopteris fertile), Rhabdotaenia, Ottokaria, Samaropsis, Notoangaridium (= Psygmophyllum) and Buriadia (See Tables 1-3).

The Siderópolis paleoflora correlates better with the lower portion of the Barakar Stage, where the domain of the genus Glossopteris is well established and the Gangamopteris-Noeggerathiopsis complex is declining (see Bernardes-de-Oliveira et al., 2011, Figure 2).

On the other hand, the paleoflora typical of the overlying upper Barakar Stage (Kungurian) is characterized by the presence of the Solenoid-complex woods (Barakaroxylon, Polysolenoxylon and Atlanticoxylon) which are similar to those of the Irati Formation in Brazilian Paraná Basin (Mussa, 1982; Prasad, 1982; Maheshwari and Bajpai, 2001; Guerra-Sommer et al., 2014).

\section{FINAL CONSIDERATIONS}

It is worth highlighting that the Gondwana Realm comprising a huge landmass including all the continents of the Southern Hemisphere and India, show a degree of 
provincialism in floral composition in different paleoclimatic belts (Maheshwari, 1992). Geographic and temporal vegetation changes in Gondwana during the late Paleozoic, ranging from periglacial/postglacial to warm temperate climatic systems throughout the Permian must have generated distinct taphofloristic patterns (Rees et al., 2002).

Additionally, some microenvironmental restrictions such as soil composition and paleoreliefs must have also been important to the establishment of different floristic composition patterns in a regional context (Ziegler et al., 1997; Rees et al., 2002). Also the influence of the sedimentary environments and distinct taphonomic processes may have affected the plant preservation in different ways and consequently can generate taxonomic bias (Looy et al., 2014).

Beyond these considerations it is worth to emphasize that taxonomic identifications of fossil plants are very subjective, making difficult to correlate assemblages that could be of a similar floristic composition (Cúneo, 1996). Floristic migrations arising from translatitudinal displacements of the continents may have led to the disappearance of some taxa and the appearance of others along these migrations and, on the other hand, may lead to consider as of similar compositions, distant and not coetaneous floras (Pfefferkorn et al., 2014).

Studying the distribution of genera occurring in the Paraná Basin, Rigby (1972) found that these genera are common in various areas of Gondwana. However, when considering the species that appear in different parts of Gondwana and found here, they indicate a provincialism in which the Paraná Basin is individualized with thirty-six endemic species in a total of seventy-seven counted species (Rigby, 1972).

All these considerations must be taken in mind when attempting correlations between the eastern and western Gondwana paleofloras as in the case of comparison between the coal flora of Siderópolis in the Paraná Basin (Brazil) and different Indian coal floras in the lower Permian.

The present study, based on paleobotanical analyses, has found more similarities between the floristic composition of the Siderópolis paleoflora, located in the upper portion of the Rio Bonito Formation (Paraná Basin, Brazil) and that of the lower Barakar Stage in India, both deposited in the Artinskian and reported from Zambezi Basin of Africa at the same latitudinal band of $\sim 50^{\circ}$ to $55^{\circ} \mathrm{S}$ (PGAP Paleogeographic Maps, Ziegler et al., 1997), See Figure 3.

It is worth to observe that several genera registered from the lower Permian of Paraná Basin are common in various areas of Eastern and Western Gondwana and the dominance of the genus Glossopteris over Gangamopteris or vice versa, is an important evidence for correlation. However, in the specific level, as pointed out by Rigby (1972), thirty-six species identified in Paraná Basin floras were endemic in

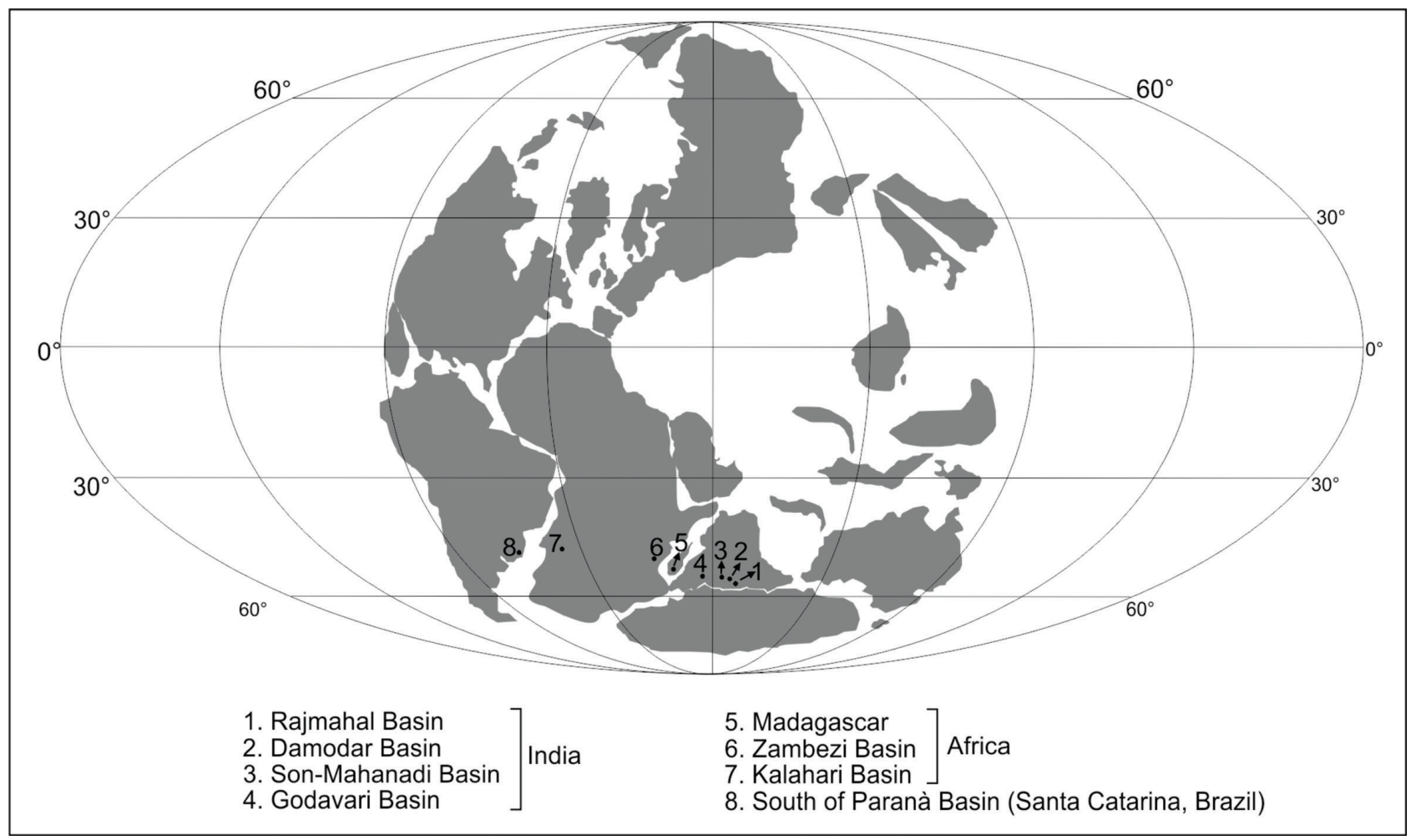

Figure 3. Paleogeographic map showing occurrences of Gondwanan Artinskian flora at the paleolatitudinal band of $\sim 50^{\circ}$ to $55^{\circ} \mathrm{S}$ (Source: Modified from: Paleolntegration Project, 2016). 
a total of seventy-seven species analyzed. Several floristic changing patterns could be a consequence, in part, of the floristic migrations arising from translatitudinal displacements of the continents.

At the upper portion of the Itarare Group (Paraná Basin), the genus Gangamopteris appears for the first time in the Cerquilho (State of São Paulo) outcrop associated with Noeggerathiopsis, with the absence of the Glossopteris genus which (Rosler, 1978; Rohn et al., 2000; Bernardes-de-Oliveira et al., 2005), however, is recorded for the first time, in the basin, although in low diversity, at the upper portion of the Itarare in basal levels of the Morro do Papaléo outcrop, in the Mariana Pimentel municipality (State of Rio Grande do Sul; Iannuzzi et al., 2010).

In India, the genus Gangamopteris appears alone at the basal portion of Talchir Stage, and also much diversified, previously than the genus Glossopteris, i.e. followed by species wide diversification in association with a less diversified genus Glossopteris (Srivastava and Agnihotri, 2010b).

Having all these considerations in mind, it can be stated that from the point of view of macrofloristic composition the Siderópolis paleoflora, located in the upper portion of the Rio Bonito Formation (Paraná Basin), correlates well with the lower portion of the Indian Gondwanan Barakar Stage where the genus Glossopteris became more expressive than the genus Gangamopteris.

This correlation is confirmed in terms of absolute age, i.e. Artinskian (according Guerra-Sommer et al., 2008, 290.1Ma, and Mori et al., 2012, 281.4 Ma), based on linking the Siderópolis Member and Palermo Formation to the late Paleozoic Third Order Sequence, Number 4 (= LPTS-4) (Holz et al., 2010) coincidentally the same time interval is attributed to the lower Barakar Stage $(=290-278 \mathrm{Ma}$, according to Mukhopadhyay et al., 2010), based on tectonic events.

\section{ACKNOWLEDGEMENTS}

This work is a contribution to the Project of International Scientific Collaboration between Brazil and India "Paleobotanical Studies in Brazilian and Indian Sedimentary Basins with special reference to the marine dinoflagellate-cysts, Gondwana Flora and their applications" sponsored by Brazil-CNPq 490829/2007-4 and India-DST RPO 24/2007. The authors thank the CNPq, Brazil and the Department of Science and Technology, India for providing the financial assistance to carry out this work. Some authors are participants of the Fellowship Program in Research Productivity of CNPq (\# PQ 304978/2013-2 - MECBO; PQ 306609/2012-6-MJG; PQ 309211/2013-1 - RI). PNPD-CAPES Scholarship Post Doctorate to MJG. The author P.S.K is thankful to the CNPq for the BJT Scholarship, No. 300578/2015-6 of the Science without Frontiers Program and to the Birbal Sahni Institute of Paleosciences for the grant of permission to come to
Brazil. The author MS is thankful to the CNPq for the PDJ Scholarship, No. 150574/2015-0. Authors also extend their thanks to the anonymous reviewers whose critical comments improved the manuscript.

\section{REFERENCES}

Bernardes-de-Oliveira, M. E. C. (1977). Tafoflora Eogondvânica da camada Irapuá, Formação Rio Bonito (Grupo Tubarão), $S C$. Thesis (Doctoral). São Paulo: Instituto de Geociências - USP.

Bernardes-de-Oliveira, M. E. C. (1978). Frutificações de Pteridospermófitas eogondvânicas da Camada Irapuá, Formação Rio Bonito, nos arredores de Criciúma, SC. XXX Congresso Brasileiro de Geologia, v. 2, 986-1001. Recife: SBG.

Bernardes-de-Oliveira, M. E. C. (1980a). Tafoflora eogondvânica da Formação Rio Bonito (camada Irapuá), Bacia do Paraná, Brasil. II Congreso Argentino de Paleontología y Bioestratigrafia / I Congreso Latinoamericano de Paleontología, v.6, 69-88. Buenos Aires: APA.

Bernardes-de-Oliveira, M. E. C. (1980b). Nouveau genre néomarioptériden fertile de la Flora à Glossopteris du Bassin de Paraná, au Brésil. Boletim IG-USP: Série Cientifica, 11, 113-119.

Bernardes-de-Oliveira, M. E. C. (1988). Equisetales eogondvânicas da Tafoflora Irapuá, Formação Rio Bonito (Permiano Inferior). Anais da Academia Brasileira de Ciencias, 60, 45-60.

Bernardes-de-Oliveira, M. E. C., Carvalho, R. G. (1981). Frutificações femininas de Glossopteridófitas da Formação Rio Bonito, Grupo Tubarão, Estado de Santa Catarina, Brasil. II Congresso Latinoamericano de Paleontologia, v. 1, 181-199. Porto Alegre: UFRGS.

Bernardes-de-Oliveira, M. E. C., Mune, S. E., Sucerquia, P., Garcia, M. J., Guerra-Sommer, M., Schmidt, I. D., Tewari, R. (2011). Mesophytic Gondwanan Paleofloras from Brazil and India: composition and paleoclimatic approach. In: I. S. Carvalho, N. K. Srivastava, O. Strohschoen Júnio, C. C. L. (Eds.), Paleontologia: cenários da vida, v. 4, 95-107. Rio de Janeiro: Interciência.

Bernardes-de-Oliveira, M. E. C., Pontes, C. E. S. (1976). Algumas observações sobre cordaitófitas da Formação Rio Bonito, Grupo Tubarão, Bacia do Paraná, Brasil. I Congresso Geológico Chileno, v. 3, L21-L81. Santiago: Universidad nacional de Chile en Santiago.

Bernardes-de-Oliveira, M. E. C., Rohn, R., Ricardi-Branco, F., Zampirolli, A. P., Mune, S. E., Amaral, P. G. C., Longhim, M. E., Castro-Fernandes, M. C., Lages, L. (2005). Late 
Carboniferous to early permian glacial related paleofloras from northeastern Paraná Basin, Brazil. XII Gondwana, 69, Mendoza: AGA.

Bernardes-de-Oliveira, M. E. C., Yoshida, R. (1981). Coniferófitas da Tafoflora Irapuá, Formação Rio Bonito, Grupo Tubarão, em Santa Catarina. Boletim de la Asociación Latinoamericana de Paleobotánicos y Palinólogos, 8, 39-55.

Chandra, S., Chandra, A. (1988). Vegetational changes and their climatic implications in coal bearing Gondwana. The Paleobotanist, 36, 74-86.

Chandra, S., Srivastava, A. K., Singh, K. J. (1992). Lower Permian plant fossils from India and early developmental history of the Glossopteris flora. Acta Paleobotanica, 32, 5-19.

Cúneo, N. R. (1996). Permian phytogeography in Gondwana. Palaeogeography, Palaeoclimatology, Palaeoecology, 125, 75-104.

Guerra-Sommer, M., Cazzulo-Klepzig, M., Santos, J. O. S., Hartmann, L. A., Ketzer, J. M., Formoso, M. L. L. (2008). Radiometric age determination of tonstein and stratigraphic constraints for the Lower Permian coal succession in southern Paraná Basin, Brazil. International Journal of Coal Geology, 74, 13-27.

Guerra-Sommer, M., Degani-Schmidt, I., Mussa, D., Kavali, P. S., Shivanna, M. (2014). The stratigraphic significance of the Solenoid Complex in the Permian of Gondwana. Geologia USP: Série Cientifica, 14(2), 139-148.

Holz, M., França, A. B., Souza, P. A., Iannuzzi, R., Rohn, R. (2010). A stratigraphic chart of the Late Carboniferous/ Permian succession of the eastern border of the Paraná Basin, Brazil, South America. Journal of South American Earth Sciences, 29, 381-399.

Holz, M., Kalkreuth, W., Banerjee, I. (2002). Sequence stratigraphy of paralic coal-bearing strata: an overview. International Journal of Coal Geology, 48(3/4), 147-179.

Iannuzzi, R. (2013). The Carboniferous-Permian floral transition in the Paraná Basin. Bulletin of New Mexico Museum of Natural History and Science, 60, 132-136.

Iannuzzi, R., Souza, P. A., Holz, M. (2010). Stratigraphic and paleofloristic record of the Lower Permian post-glacial succession in the southern Brazilian Paraná Basin. Geological Society of America. Special Paper, 468, 113-132.

Jasper, A., Guerra-Sommer, M., Abu, H., Abdalla, M. P., Bamford, M., Bernardes-de-Oliveira, M. E. C., Tewari, R., Uhl, D. (2013). The Burning of Gondwana: permian fires on the southern continent: a paleobotanical approach. Gondwana Research, 24, 148-160.

Khan, A., Shahnawaz, A. (2013). Petrography and provenance of Early Triassic Pachmarhi formation sandstones, Satpura
Gondwana Basin, Madhya Pradesh, Central India. Open Journal of Geology, 3, 83-93.

Looy, C. V., Kerp, H., Duijnstee, I. A. P., DiMichele, W. A. (2014). The late Paleozoic ecological-evolutionary laboratory, a land-plant fossil record perspective. The Sedimentary Record, 12(4), 4-10.

Maheshwari, H. K. (1992). Provincialism in Gondwana floras. In: B. S. Venkatachala, H. P. Singh (Eds.), Four decades of Indian Paleobotany. The Paleobotanist, 40, 101-127.

Maheshwari, H. K., Bajpai, U. (2001). Phytostratigraphical succession in the Glossopteris flora of India. Revista Universidade Guarulhos: Geociências, 6(6), 22-34.

Menezes, J. R. C. (2000). Estratigrafia do Neopermiano da Bacia do Paraná no Rio Grande do Sul. In: M. Holz, L. F. De Ros (Eds.), Geologia do Rio Grande do Sul, 323-334. Porto Alegre: Editora da Universidade Federal do Rio Grande do Sul.

Milani, E. J. (1997). Evolução tectono-estratigráfica da Bacia do Paraná e seu relacionamento com a geodinâmica fanerozóica do Gondwana sul-ocidental. Thesis (Doctoral). Porto Alegre: Instituto de Geociências - UFRGS.

Milani, E. J., Faccini, U. F., Scherer, C. M. S., Araújo, L. M., Cupertino, J. A. (1998). Sequences and stratigraphic hierarchy of the Paraná Basin (Ordovician to Cretaceous), Southern Brazil. Boletim IG-USP: Série Cientifica, 29, 125-173.

Milani, E. J., Melo, J. H. G., Souza, P. A., Fernandes, L. A., Franca, A. B. (2007). Bacia do Paraná. Boletim de Geociências da Petrobrás, 15(2), 265-287.

Mori, A. L. O., Souza, P. A., Marques, J. C., Lopes, R. C. (2012). A new U-Pb zircon age dating and palynological data from a Lower Permian section of the southernmost Paraná Basin, Brazil: Biochronostratigraphical and geochronological implications for Gondwanan correlations. Gondwana Research, 21, 654-669.

Mukhopadhyay, G., Mukhopadhyay, S. K., Roychowdhury, M., Parui, P. K. (2010). Stratigraphic correlation between different Gondwana basins of India. Journal of the Geological Society of India, 76, 251-266.

Mussa, D. (1982). Lignitafofloras permianas da bacia do Paraná (Estados de São Paulo e Santa Catarina), 2 v. Thesis (Doctoral). Porto Alegre: Instituto de Geociências - UFRGS.

Navale, G. K. B. (1979). Lower Gondwana primary composite genetic coal types of India. CR (East Lansing, Mich.), 4, 62-67.

Navale, G. K. B., Saxena, R. (1989). An appraisal of coal petrographic facies in Lower Gondwana (Permian) coal 
seams of India. International Journal of Coal Geology, 12(1-4), 553-588.

PaleoIntegration Project. (2016). Tucson: University of Arizona. Accessed on 15 March 2016, <http://www.geo. arizona.edu/ rees/Artpgeoglarge.html $>$

Pant, D. D. (1996). The biogeography of the late Paleozoic floras of India. Review of Palaeobotany and Palynology, 90, 79-98.

Pfefferkorn, H. W., Alleman, V., Iannuzzi, R. (2014). A greenhouse interval between icehouse times: Climate change, long-distance plant dispersal, and plate motion in the Mississippian (late Visean-earliest Serpukhovian) of Gondwana. Gondwana Research, 25, 1338-1347.

Prasad, M. N. V. (1982). An annotated synopsis of Indian PaleoPaleozoic gymnospermous woods. Review of Palaeobotany and Palynology, 38(1), 119-156. http://dx.doi. org/10.1016/0034-6667(82)90053-7.

Rees, P. M. (2002). Land-plant diversity and the end-Permian mass extinction. Geology, 30(9), 827-830.

Rees, P. M., Gibbs, M. T., Ziegler, A. M., Kutzbach, J. E., Behling, P. T. (1999). Permian climates: evaluating model predictions using global paleobotanical data. Geology, 27(10), 891-894.

Rees, P. M., Ziegler, A. M., Gibbs, M. T., Kutzbach, J. E., Behling, P. J., Rowley, D. B. (2002). Permian Phytogeographic patterns and climate data/model comparisons. The Journal of Geology, 110, 1-31.
Rigby, J. F. (1972). The distribution of lower Gondwana plants in the Paraná basin of Brazil. In: S. H. Haughton (Ed.), II Gondwana Symposium 1970, 575-584. Pretoria: Counc. Sci. Ind. Res. Pretoria.

Rohn, R., Longhim, M. E., Bernardes-de-Oliveira, M. E. C., Navarro, G. R. B. (2000). Nova ocorrência fitofossilífera neocarbonífera-eopermiana do Subgrupo Itararé, à margem esquerda do rio Capivari, município de Tietê, SP, Brasil. Revista Universidade Guarulhos: Geociências, 5, 57-61.

Rosler, O. (1978). The Brazilian eogondwanic floral successions. Boletim IG-USP, 9, 85-91.

Scotese, C. R. (2002). Plate tectonic maps and continental drift animations: PALEOMAP Project. Accessed on 19 November 2015, <www.scotese.com>

Srivastava, A. K., Agnihotri, D. (2010a). Morphological consequence of Gangamopteris McCoy in Glossopteris flora. Journal of Asian Earth Sciences, 39, 760-769.

Srivastava, A. K., Agnihotri, D. (2010b). Upper Permian plant fossil assemblage of Bijori Formation: a case study of Glossopteris flora beyond the limit of Raniganj Formation. Journal of the Geological Society of India, 76, 47-62.

Ziegler, A. M., Hulver, M. L., Rowley, D. B. (1997). Permian world topography and climate. In: I. P. Martini (Ed.), Late glacial and postglacial environmental changes: quaternary, Carboniferous-Permian and Proterozoic, 111-146. Oxford: Oxford University Press. Accessed on 06 October 2015, $<$ http://www.geo.arizona.edu/ rees/Artpgeoglarge.html> 


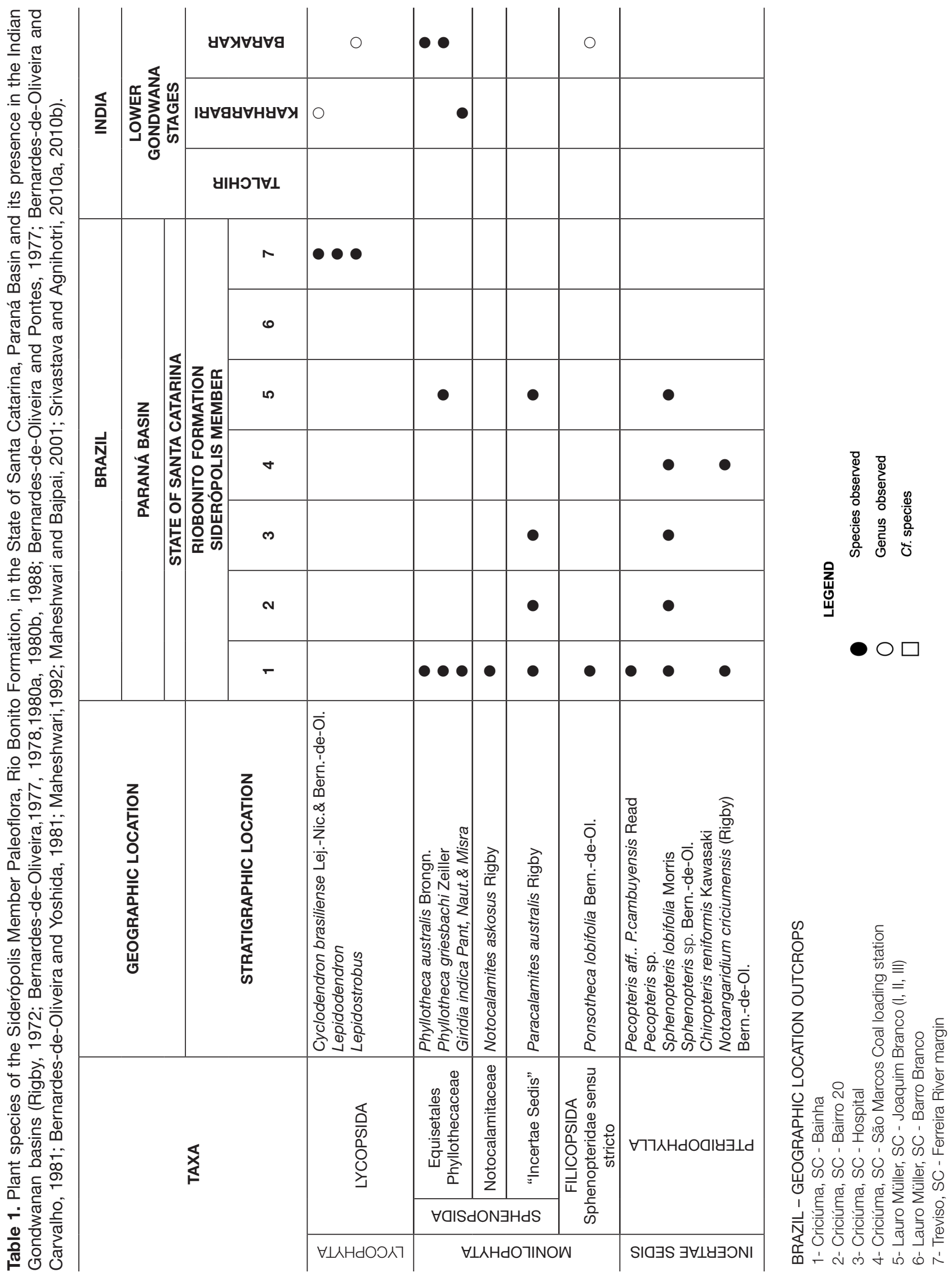




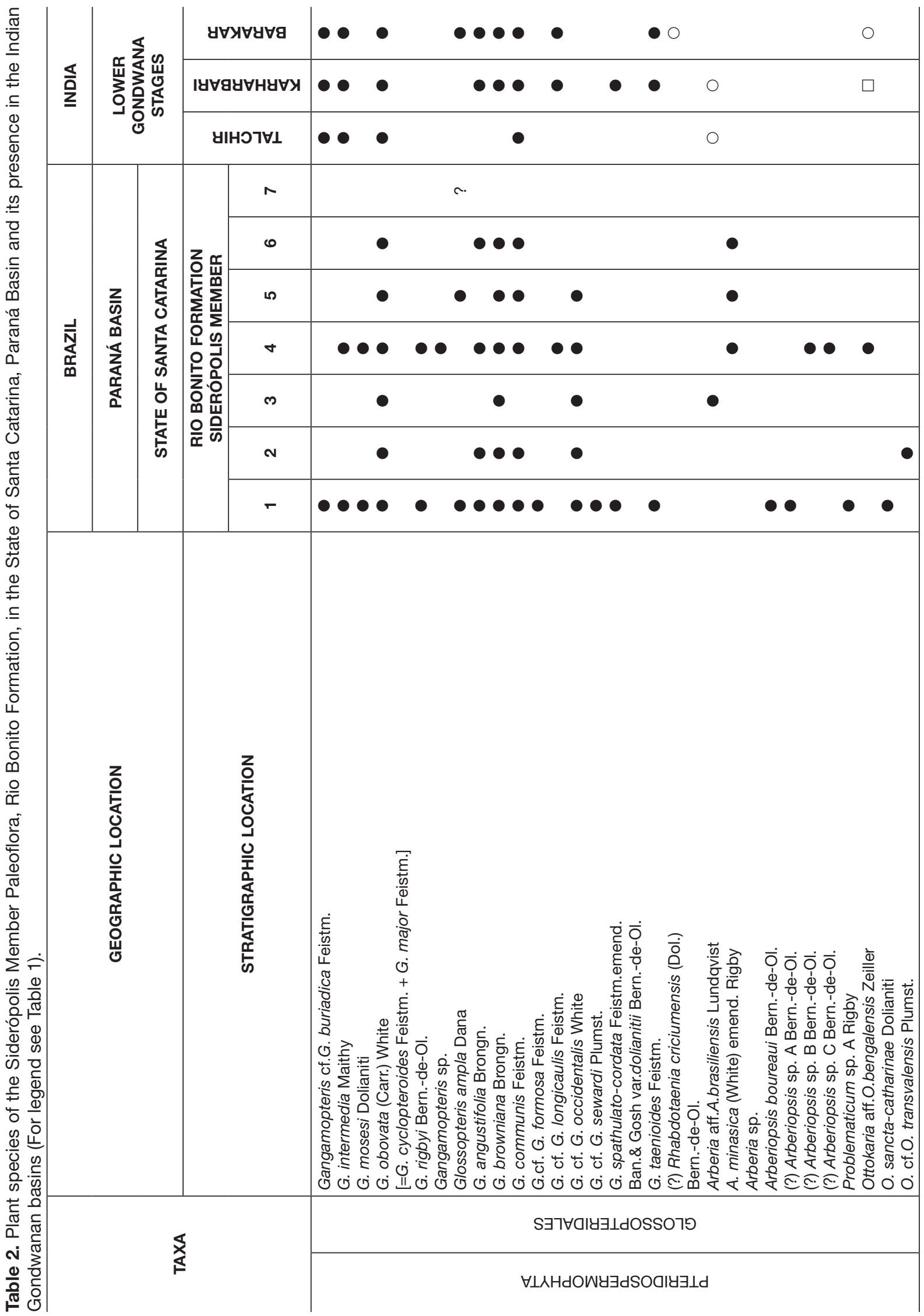




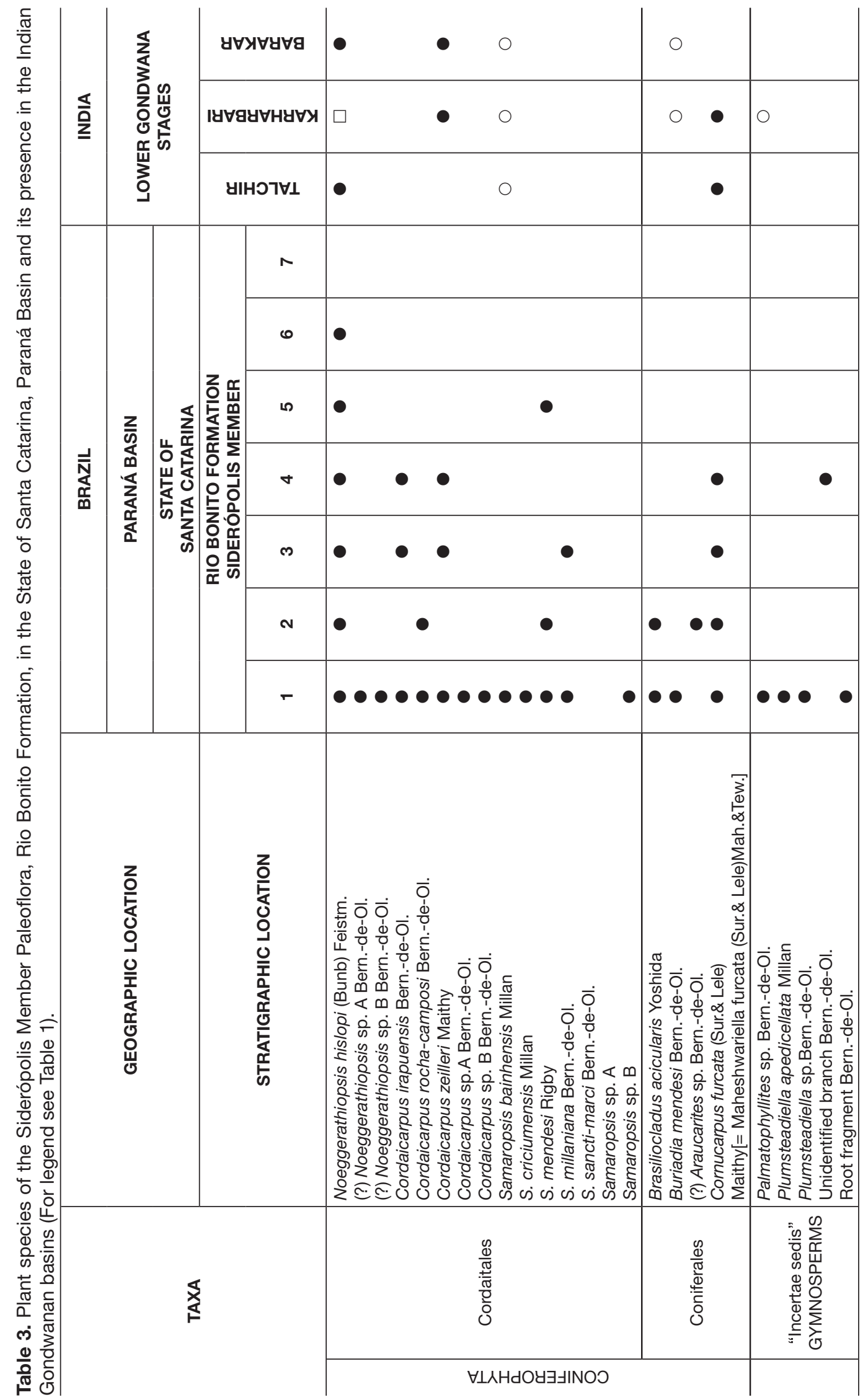

